\title{
Prospects for the Internal State Financial Control Development in the Russian Federation
}

\author{
Submitted 21/08/19, 1st revision 30/09/19, 2nd revision 25/10/19, accepted 29/11/19
}

\begin{abstract}
S.S. Galazova ${ }^{1}$, O.I. Karepina ${ }^{2}$,T.F. Romanova ${ }^{3}$
Abstract:

Purpose: The presented article is aimed at assessing the modern development of internal state financial control in the Russian Federation. The most important condition for the effective functioning of public finances is the transition to a qualitatively new level required for the dynamic development of the public administration sector, improving the social status of citizens, as well as the investment climate. This predetermines the objective need to rethink and identify fundamentally new approaches to the study of theoretical, methodological and practical problems of financial management.
\end{abstract}

Design/Methodology/Approach: The article is a comprehensive review of the main changes in legislation governing internal state financial control that determines the nature of this concept, the methodology of internal state financial control is presented, problems are identified, substantiated and structured and directions for their solution are proposed in order to increase its development effectiveness. The study used methods of comparative analysis, systematization, classification, analogy and comparison.

Findings: The authors identified, substantiated the problems and developed recommendations for improving internal state financial control, which can improve the quality of public and municipal finance management and facilitate the transfer of public administration to a level that meets the needs of modern reform of the Russian economy.

Practical Implications: The results of the study can be introduced into the practice of organizing internal state financial control in the Russian Federation in order to improve the quality of public and municipal finance management.

Originality/Value: The main contribution of this study is to develop recommendations for the development of internal state financial control, which will contribute to the effective management of public finances in the executive bodies of the Russian Federation.

Keywords: State financial control, internal state financial control, development.

JEL Code: G29.

Paper type: Research note: Internal Financial Control.

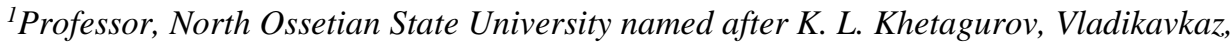
Russian Federation.

${ }^{2}$ Associate Professor, Department of finance, Rostov State University of Economics, Rostovon-Don, Russian Federation, karepindima@mail.ru

${ }^{3}$ Professor, Department of finance, Rostov State University of Economics, Rostov-on Don. 


\section{Introduction}

The most important condition for the public finances' effective functioning is the transition to a qualitatively new level required for the public administration sector' dynamic development, improving the social status of citizens, as well as the investment climate. This predetermines the objective need to rethink and identify fundamentally new approaches to the study of theoretical, methodological and practical problems of financial management. The key role in financial management, in our opinion, belongs to the internal state financial control (Karepina, 2018; Anureev, 2017). Internal state financial control is a continuous process carried out by the budget funds chief administrator (administrator) structural units' head and officials who organize and execute, as well as ensure compliance with the internal procedures for budget preparation and execution, budget accounting and budget reporting.

The need to organize internal state financial control is of relevance and determines the program-oriented planning principles' requirements. It is worth noting that when creating a rational system of internal financial control, an efficiently functioning control environment covering all the structural divisions and helping the management to take administrative decisions aimed at further improving of the financial management quality, identifying and leveling risks, an effective internal financial control system has appeared (Karepina et al., 2019; Denisova et al., 2017).

\section{Theoretical, Informational, Empirical and Methodological Grounds}

At the present stage of the internal state financial control system development, there is a regulatory document governing the internal state financial control implementation - Ministry of Finance Order of Russia N 356 “On Approval the Methodological Recommendations for the Internal Financial Control Implementation" of September 7, 2016 (Ivanova et al., 2016) developed with the purpose to help executive bodies to organize regulated work on the internal state financial control implementation as presented in Figure 1.

\section{Results}

It is worth noting that the Federal Law of 26.07.2019 No. 199-FL "On Amending The Budget Code of the Russian Federation regarding the improvement of state (municipal) financial control, internal financial control and internal financial audit" amended Chapter 26 of the Budget Code of the Russian Federation, clarifying and supplementing the powers of the bodies of internal state financial control with regard to:

- compliance with the provisions of legal acts regulating budgetary legal relations, including those establishing the requirements for accounting and the preparation and submission of accounting (financial) statements of state institutions; 
Figure 1. Internal Financial Control Methodology

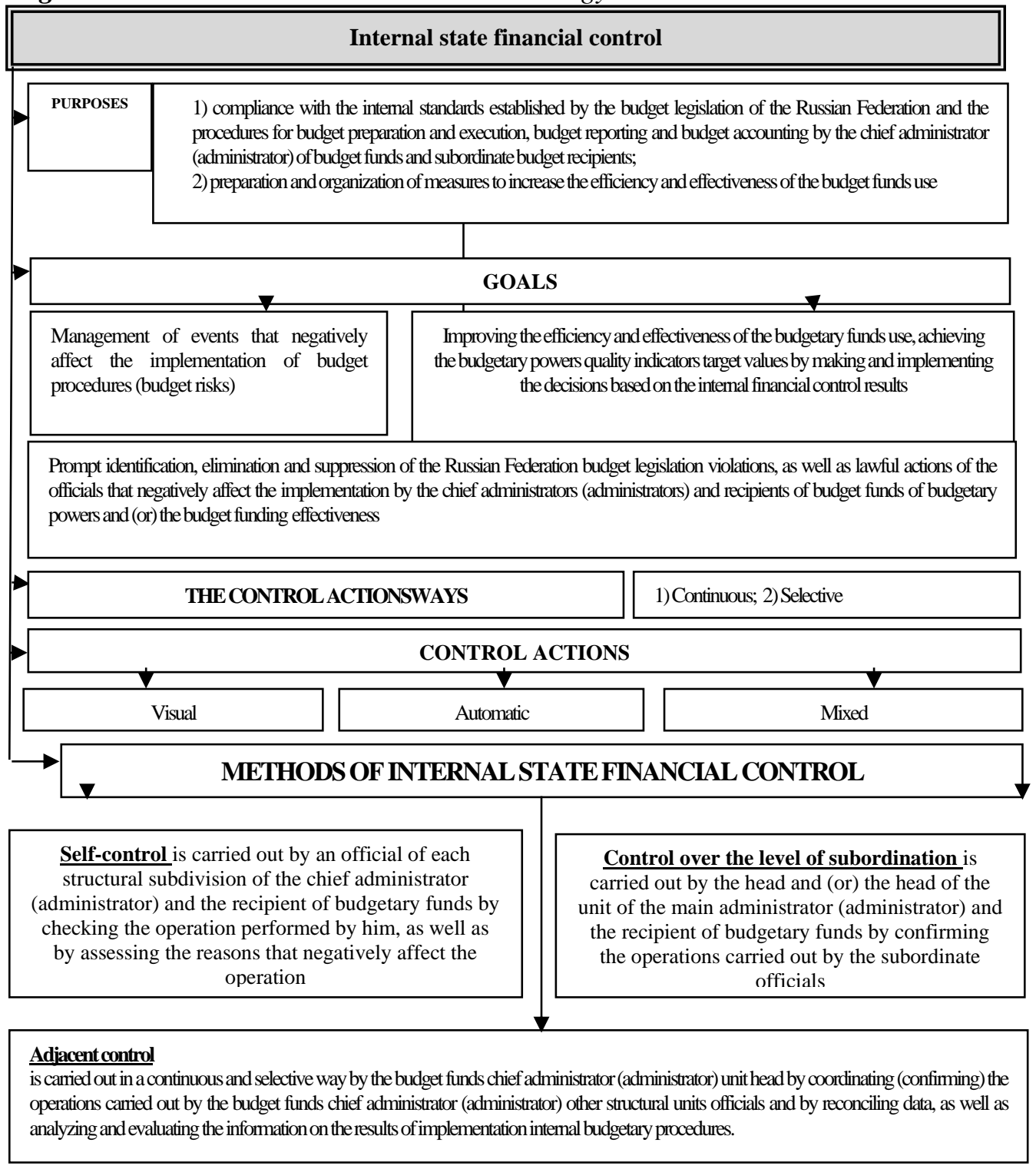

\section{Jurisdiction control}

is carried out in order to exercise the budgetary powers by the chief administrator (administrator) of budgetary funds in a continuous and selective manner in relation to the procedures performed by the subordinate managers and budgetary funds recipients by conducting checks aimed at establishing the submitted documents' compliance with the requirements of regulatory legal acts, internal standards and procedures, and by collecting, analyzing and evaluating the information about the organization and the results of internal budgetary procedures subordinate administrators of budget funds and budget funds recipients. 
- compliance with the provisions of legal acts stipulating the public regulatory obligations and the obligations for other payments to individuals from the budgets of the Russian Federation budget system, as well as compliance with the terms of contracts (agreements) on the funds provision from the corresponding budget, state (municipal) contracts;

- compliance with the terms of contracts (agreements) concluded with a view to the execution of contracts (agreements) on the funds provision from the budget, as well as in cases provided for by the RF Budget Code, the terms of contracts (agreements) concluded with a view to the state (municipal) contracts' execution;

- the reliability of reports on the results of the provision and use of budget funds, including the reports on the state programs implementation, reports on the state tasks implementation, reports on the achievement of performance indicators for the provision of funds from the budget.

When implementing the control events on internal state financial control, the powers presented in Figure 2 are exercised.

Figure 2. Control measures of internal state financial control

\begin{tabular}{|c|}
\hline CONTROL EVENTS OF THE INTERNAL STATE FINANCIAL CONTROL \\
\hline To carry out checks, audits and examinations; \\
\hline To send acts, conclusions, representations and (or) instructions to the control objects; \\
\hline $\begin{array}{l}\text { To send notifications of the budgetary coercive measures' application to financial authorities (governing } \\
\text { bodies of state extra-budgetary funds); }\end{array}$ \\
\hline $\begin{array}{l}\text { To carry out the proceedings on administrative violations in the manner prescribed by the legislation on } \\
\text { administrative violations; }\end{array}$ \\
\hline To organize the conduct of expertise necessary for inspections, audits and examinations; \\
\hline $\begin{array}{c}\text { To receive the necessary access to state and municipal information systems necessary for the internal state } \\
\text { (municipal) financial control implementation in accordance with the legislation of the Russian Federation } \\
\text { on information, information technologies and information protection, the legislation of the Russian } \\
\text { Federation on state and other secrets protected by law. }\end{array}$ \\
\hline
\end{tabular}

The implementation of the control measures in the figure presented by the authors has its own innovations reflected in the last two events: conducting the examinations necessary to conduct inspections, audits and examinations and gaining constant access to state and municipal information systems, information technologies in the implementation of internal state financial control, which will be available for putting into practice only from July 1, 2020. 


\section{Conclusions and Recommendations}

The dynamic development of the internal state financial control system involves the solution of some problems. In the context of economic uncertainty, in our opinion, it is necessary to develop the internal state financial control, which will contribute to the effective management of public finances in executive bodies (Ivanova et al., 2017; Ivanova et al., 2016; Romanova et al., 2018). The internal state financial control effective system construction is associated with the solution of many problems requiring a rigorous solution.

Firstly, the legal regulation and methodology of internal state financial control should be finalized. Work is underway on organization issues, the process of forming control has not yet been finalized. It is a question of creating the internal state financial control standards, a unified procedure for conducting internal state financial control, which should be uniform in views on the goals, objectives, forms and methods of organizing the internal state financial control. It is a unified view of these issues that will create a strong foundation for the system of internal state financial control in Russia, therefore, in our opinion, this is a key problem. It seems to us that the internal state financial control federal standards should contain:

- the principles of control activities of the internal state financial control bodies;

- the rights and obligations of the internal state financial control bodies officials including, regarding the examinations' organization, the rights and obligations of control objects, organizational and technical support for audits and inspections;

- the rules for planning, conducting examinations, audits and inspections, processing and implementation of their results, including the rules for extending the deadline for the submission and prescription;

- the rules for reporting the results of the internal state financial control bodies' control activities;

- the rules for pre-trial appeal of decisions and actions (inaction) of the internal state financial control bodies and their officials.

Secondly, the development direction is the leveling of the ensuring functional independence problems, the solution of which is necessary to increase the internal state financial control effectiveness. This issue was raised at the Moscow Financial Forum on September 13, 2019 at the panel discussion "Development of a financial control and audit system in the public administration sector: today and tomorrow". The participants noted that independence is necessary for the internal state financial control objectivity. The issue now remains unresolved and requires further study.

Thirdly, there is an objective need to develop a mechanism for interaction when approving the future control measures plans by the control bodies. A very serious issue that needs to be addressed in the field of the state financial control is the state financial control bodies' complex structure, which in turn leads to the fact that the 
state financial control bodies' tasks are not detailed enough, the boundaries of responsibility are blurred, and coordination is very weak. The bodies of external and internal state financial control must clearly and harmoniously interact with each other, but at the same time preserving individuality. Such interaction seems to be implemented on the Portal of State and Municipal Financial Audit (SIS UNSFC) platform.

In modern conditions, Russia is characterized by a period of active development and implementation of various forms of digitalization in the field of state and municipal finances. Information technology as a result of the advanced science achievements has opened new real opportunities in improving the qualitative characteristics of financial control in the system of state and municipal government. With the information technology development, network services and digital resources, a real prospect to bring control activities in the public administration system to a qualitatively new level has been opened. The digital economy capabilities should be used with the greatest degree of efficiency when conducting internal state financial control, which will lead to reduction in the cost of material, labor, financial resources, the level of error in the obtained control results is also reduced, and the degree of accuracy and objectivity is increased.

In other words, the use of digital technologies in internal state financial control minimizes the human factor, which will not only positively affect objectivity and ensure a reduction in error, but also reduce the corruption risk in public administration.

Moreover, it automates the collection and analysis of forecast, planned, statistical information and reporting, monitoring, sociological research, and also provides greater openness and transparency of the state financial bodies activities. The portal of state and municipal financial audit (SIS UNSFC), as a tool for coordinating external and internal state financial control, performs the following tasks:

- ensures the state financial control publicity in the field of budget relations;

- provides an opportunity to analyze the control activities frequency, including those aimed at avoiding duplication in the control objects, as well as the establishment of the frequency of control activities, based on the risks of the activities of the objects of control;

- creates a unified information system in the Russian Federation, accumulating the possibilities of recording and obtaining information on the state control bodies' activities, the number of which currently stands at more than 2.5 thousand bodies;

- generates structured data on the implementation of state financial control in the Russian Federation and, thus, provides the possibility of applying the necessary approaches, methods and tools of information technologies for processing these data; - determines the state financial control subject based on analysis and processing of information in the SIS UNSFCon the internal financial control conduct in the objects of external state audit, as well as their application of these measures' results; 
- promotes the use by all the state financial control bodies in the implementation of control measures of a single classifier in order to ensure accounting uniformity, analysis and results of measures taken.

Thus, in conditions of economic uncertainty, internal state financial control is focused on the prevention of inappropriate, inefficient budget funds spending and government spending optimization. Consequently, in the process of developing internal state financial control in Russia, it is necessary to solve the problems identified in the article, which will improve the quality of public and municipal finance management and will help transfer the public administration system to a level that meets the needs of the Russian economy' modern reform.

\section{References:}

Anureev, V.S. 2017. Reconfiguration of Financial System Elements to Restore Economic Growth: The System Simplicity and Transformation towards State-Based and Corporate-Based Types. European Research Studies Journal, 20(2A), 281-307.

Denisova, P.I., Rukina, N.S., Samoylova, N.K., Takmazyan, S.A. 2017. Financial Instruments of the Socially Responsible Economy. European Research Studies Journal, 20(1), 284-293.

Ivanova, O.B., Bogoslavtseva, L.V., Karepina, O.I., Kostoglodova, E.D. 2017. Providing the Budget Transparency and State Projects Efficiency Monitoring in Russia. European Research Studies Journal, 20(1), 97-104.

Ivanova, O.B., Vovchenko, N.G., Kostoglodova, E.D., Bogoslavtseva, L.V., Rukina, S.N., Karepina, O.I. 2017. Financial transparency in budget sector of economy as a necessary condition of clustering. International Journal of Trade and Global Markets, 2-3(10), 207-216.

Karepina, O.I. 2018. The development of internal state financial control in Russia. Audit statements, 2, 54-57.

Karepina, O.I., Bogoslavtseva, L.V., Bogdanova, O.Yu. 2019. The development of state financial control in the context of program and project budgeting. Humanitarian, socio-economic and social sciences, 4, 204-211.

Romanova, T.F., Bogoslavtseva, L.V., Karepina, O.I., Bogdanova, O.Y. 2018. Conceptual approaches in providing the effective and responsible management of state programs management. European Research Studies Journal, 21(4), 261-272. 